\title{
Effect of 3-Amino-1,2,4-triazole on Microstructure and Properties of Maleated HDPE/Maleated EPDM Blend
}

\author{
Tae Hyun Kim, Young-Wook Chang ${ }^{\dagger}$, Yong Woo Lee*, and Dong Hyun Kim ${ }^{* *}$ \\ Department of Fusion Chemical Engineering, Hanyang University, Ansan 426-791, Korea \\ *Department of Chemistry and Applied Chemistry, Hanyang University, Ansan 426-791, Korea \\ ${ }^{* *}$ Convergent Technology, R\&D Division, Korea Institute of Industrial Technology, Ansan 426-910, Korea \\ (Received January 16, 2014, Revised January 27, 2014, February 26, Accepted March 5, 2014)
}

\section{3-Amino-1,2,4-triazole0| Maleated HDPE/Maleated EPDM 블렌드의 미세구조 및 물성에 미치는 영향}

\author{
김태현 · 장영욱 ${ }^{\dagger} \cdot$ 이용우 ${ }^{*} \cdot$ 김동현 ${ }^{*}$ \\ 한양대학교 융합화학공학과 \\ *한양대학교 응용화학과 \\ **한국생산기술연구원 융복합연구부문 \\ 접수일 (2014년 1월 16일), 수정일(1차:2014년 1월 27일, 2차:2월 26일), 게재확정일(2014년 3월 5일)
}

\begin{abstract}
Amino-1, 2, 4-triazole (ATA) (2.5 and $5.0 \mathrm{phr}$ ) was incorporated into a immiscible maleated ethylene propylene diene rubber(mEPDM)/maleated high density polyethylene(mHDPE) $(50 \mathrm{wt} \% / 50 \mathrm{wt} \%)$ blend by melt mixing. Effects of the ATA on structure, mechanical and rheological properties of the blend was investigated. FT-IR and DMA results revealed that supramolecular hydrogen bonding interactions between the polymer chains occur by reaction of ATA with maleic anhydride grafted onto the component polymers in the blend, which induces the physical crosslinks in the blend. FE-SEM analysis showed that mEPDM forms a dispersed phase in continuous mHDPE matrix, and the blend with the ATA has finer phase morphology as compared to the blend without the ATA. By the addition of ATA in the blend, there were significant increases in tensile strength, modulus and elongation-at-break as well as elastic recoverability. Melt rheology studies revealed that ATA induced substantial increase in storage modulus and complex viscosity of the blend at the melt state.
\end{abstract}

요 약 : 3-Amino-1,2,4-triazole(ATA)을 비상용성 블렌드인 maleated HDPE(mHDPE)/maleated EPDM (mEPDM) (50 wt\%/50 wt\%)에 용융혼합에 의해 $2.5 \mathrm{phr}, 5.0 \mathrm{phr}$ 첨가하였으며, ATA 첨가에 따른 블렌드의 미세구 조, 기계적물성 및 유변물성을 FT-IR, FE-SEM, 인장시험, $\mathrm{DMA}$ 및 $\mathrm{ARES}$ 를 이용하여 각각 조사하였다. FTIR 및 $\mathrm{DMA}$ 분석결과 용융혼합 과정에서 $\mathrm{ATA}$ 가 $\mathrm{mHDPE}$ 및 $\mathrm{mEPDM}$ 의 말레무수물과 반응하여 초분자적 수소결합이 형성되며, 이로부터 물리적 가교구조가 형성되는 것을 알 수 있었다. $\mathrm{FE}-\mathrm{SEM}$ 분석결과 $\mathrm{mHDPE} / \mathrm{mEPDM}$ 블렌드는 플라스틱인 $\mathrm{HDPE}$ 가 연속상을 이루고 고무상인 $\mathrm{EPDM}$ 이 분산상을 이루며 $\mathrm{ATA}$ 를 첨가함으로써 모폴로지가 더욱 미세해짐을 알 수 있었다. 인장물성시험결과 ATA에 첨가에 의해 형성된 물리적가교구조로 인해 인장강도, 모듈러스, 파단신율 값 및 탄성복원력이 증가되었으며, 용융레올로지 특성 분석결과 ATA가 첨가됨으로써 블렌드의 저장탄성율 과 용융점도가 증가됨을 알 수 있었다.

Keywords : maleated EPDM/maleated HDPE blend, 3-amino-1, 2, 4-triazole (ATA), supramolecular hydrogen bonding network

\section{I . Introduction}

Polymer blending has been recognized as an effective way to develop a new polymeric material with improved performance properties. Elastomer/thermoplastic blend is an important

\footnotetext{
${ }^{\dagger}$ Corresponding Author. E-mail: ywchang@hanyang.ac.kr
}

class of the polymer blends, which can be applicable as toughened plastics or thermoplastic elastomers depending upon the composition and morphology of the blends. ${ }^{1-6}$

Generally, most of the elastomer/thermoplastic blends are immiscible and proper compatibilization is needed for the blends to have desirable properties. Various compatibilization techniques have been explored, which include reactive blend- 
ing including dynamic vulcanization ${ }^{7-10}$ and addition of a third component into the blend. ${ }^{11-18}$ In the dynamically vulcanized blends, in which rubber phase is vulcanized during melt mixing of the rubber and thermoplastic, fine dispersion of rubber particles in continuous thermoplastic phase can be achieved with enhanced strength, modulus and elongation at break of the blend as compared to simple blend. ${ }^{9,10}$ Antony et al. reported that addition of $\mathrm{ZnO}$ into immiscible carboxylated polyolefin blends can induce improved performance properties of the blends via the formation of ionic interactions between the component polymers. ${ }^{13-17}$ Phan et al. employed polyetheramine as a compatibilizer of the maleated $\mathrm{PP} /$ maleated rubber blends to improve their mechanical properties. ${ }^{18}$

Thermoreversible rubber network based on supramolecular hydrogen bonding between rubber chains has been studied. ${ }^{19-21}$ These studies revealed that supramolecular hydrogen bonding between the rubber chains can be obtained from the reaction of amino functionality of 3-amino-1,2,4-triazole (ATA) with maleic anhydride grafted onto the rubber chain during melt mixing of ATA with a maleated rubber. Chang et al employed this concept to a polymer blend system and developed a thermoplastic elastomer by the addition of ATA into maleated HDPE/maleated EPDM blend. ${ }^{22,23}$

In the present study, we investigated the effect of ATA on phase morphology, mechanical and rheological properties of maleated EPDM/maleated HDPE (50 wt $\% / 50 \mathrm{wt} \%$ ) blend.

\section{Experimental}

Maleated ethylene propylene diene rubber (Royaltuf 485) with maleic anhydride content of $0.5 \mathrm{wt} \%$ (hereafter referred to as $\mathrm{mEPDM}$ ) and maleated high density polyethylene with maleic anhydride content of $1 \mathrm{wt} \%$ (hereafter referred to as mHDPE) were purchased from Uniroyal Chemical Co. 3-Amino -1, 2, 4-triazole (ATA) was purchased from Sigma Aldrich Co. The $\mathrm{mEPDM} / \mathrm{mHDPE}(50 \mathrm{wt} \% / 50 \mathrm{wt} \%$ ) blend with ATA content of $0,2.5$, and $5.0 \mathrm{phr}$ was prepared by a melt mixing in Haake internal mixer at $170^{\circ} \mathrm{C}$ for $10 \mathrm{~min}$. with $60 \mathrm{rpm}$ of rotor speed. The each sample was encoded as SATA-0 (0 phr ATA), SATA-2.5(2.5 phr ATA), and SATA-5 (5.0phr ATA), respectively. The mixed sample was then molded (as a sheet) at $200^{\circ} \mathrm{C}$ in an electrically heated hot press.

Tensile tests were conducted by universial testing machine (United Co. STM 10 E) at a crosshead speed of $50 \mathrm{~mm} / \mathrm{min}^{-1}$. At least 10 samples were tested to ensure the reproducibility of the results. Tension set was measured to evaluate elastic recoverability of the samples. The samples were stretched to $100 \%$ elongation and keeping them in that position for $10 \mathrm{~min}$, and length of the sample after the release of the applied stress was measured. The tension set was determined by following formula:
Tension set $(\%)=$

(change in length /original length) $\times 100$

X-ray diffraction experiment was carried out between $2 \theta$ $=10-30^{\circ}$ with $\mathrm{CuK} \alpha$ radiation at a generation voltage of 40 $\mathrm{kV}$ in a Rigaku $2500 \mathrm{PC}$ diffractometer.

The degree of crystallinity $(X c)$ was measured by using following formula: ${ }^{24}$

$$
\mathrm{Xc}=\mathrm{Ic} /(\mathrm{Ia}+\mathrm{Ic})
$$

where Ic and Ia are the integration of the peaks corresponding to crystalline and amorphous phase, respectively.

Dynamic mechanical tests were performd by using a dynamic mechanical analyzer (TA instrument 2980). Samples were subjected to a cyclic tensile strain with an amplitude of $0.2 \%$ at a frequency of $10 \mathrm{~Hz}$. The tempearture was increased at a heating rate of $10^{\circ} \mathrm{C} \mathrm{min}^{-1}$ over the range from -100 to $175^{\circ} \mathrm{C}$. Melt rheological behavior was analyzed using a RMS (Rheometrics Scientific Inc.) instrument at a strain of $0.5 \%$ (which is in linear range) within the frequency range of 0.01 to 100 at $150^{\circ} \mathrm{C}$. For the observation of phase morphology of the blend, the sample was fractured cryogenically and the fractured surface was etched using xylene at room temperature for 6 hours to remove the EPDM phase. Phase morphology of the blends was observed using a JEOL JSM-630F instrument.

IR analysis was carried out on a thin film using a Varian 800 FT-IR in frequency range of $400-4000 \mathrm{~cm}^{-1}$.

\section{Results and Discussion}

FTIR spectra of SATA-0, SATA-2.5, and SATA-5 are shown in Figure 1(a), (b) and (c), respectively. The FTIR spectra of SATA-0 has two absorption peaks at $1786 \mathrm{~cm}^{-1}$ and $1863 \mathrm{~cm}^{-1}$, which are due to stretching vibrations of the maleic anhydride group of $\mathrm{mEPDM}$ and mHDPE. The absorption peaks corresponding to the maleic anhydride are absent in FTIR spectra of SATA-2.5 and SATA-5. This suggests that all of maleic anhydride groups existed on the polymer chains reacted with the amino group of ATA. A broad peak between 2400-3400 $\mathrm{cm}^{-1}$ as well as two peaks at $1727 \mathrm{~cm}^{-1}$ and 1724 $\mathrm{cm}^{-1}$ in the SATA-2.5 and SATA-5 indicate that carboxylic acid groups are produced in the blend with ATA and these are involved in hydrogen bondings. And, two absorption peaks at $1528 \mathrm{~cm}^{-1}$ and $1639 \mathrm{~cm}^{-1}$ in SATA-5 and those at 1536 $\mathrm{cm}^{-1}$ and $1635 \mathrm{~cm}^{-1}$ in SATA-2.5 indicate the presence of five membered triazole unit in the blend with ATA. All of these results indicate that the ATA is covalently bonded to the polymer chains in the blend, and the resultant supramolecular hydrogen bonding interactions can occur at the interface region 


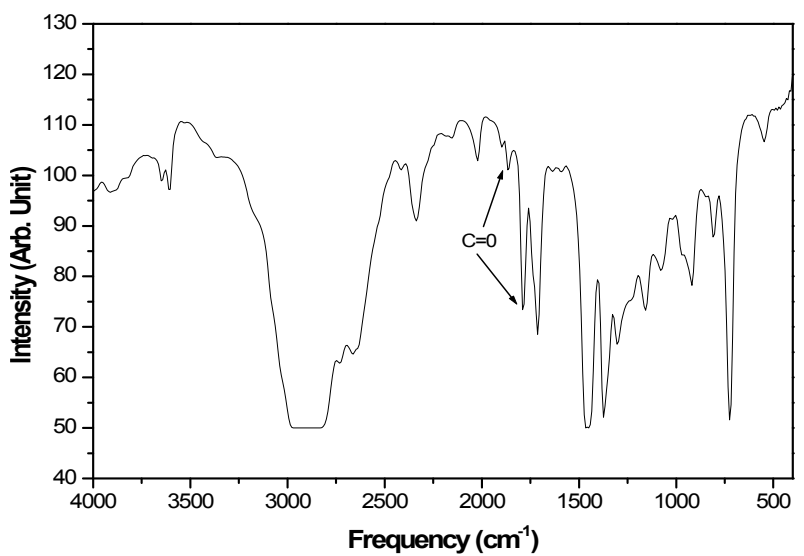

Figure 1(a). IR spectra of SATA-0.

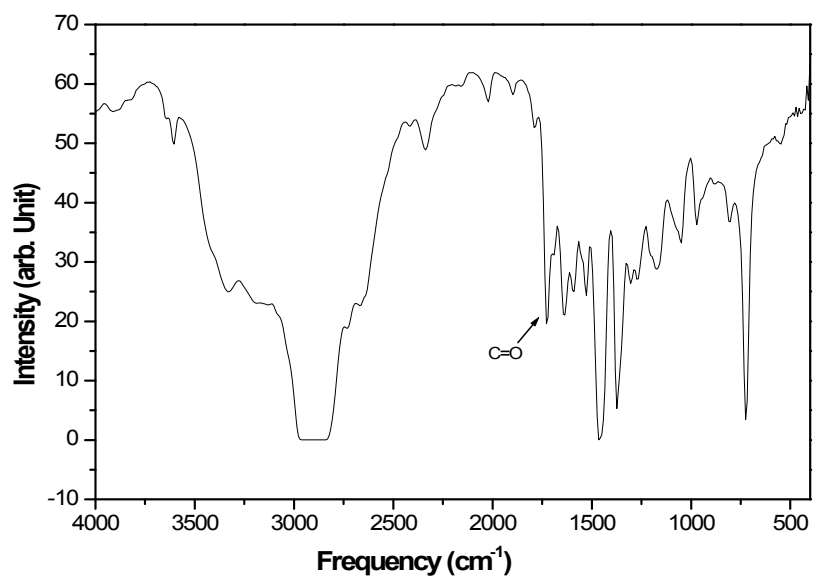

Figure 1(b). IR spectra of SATA-2.5.

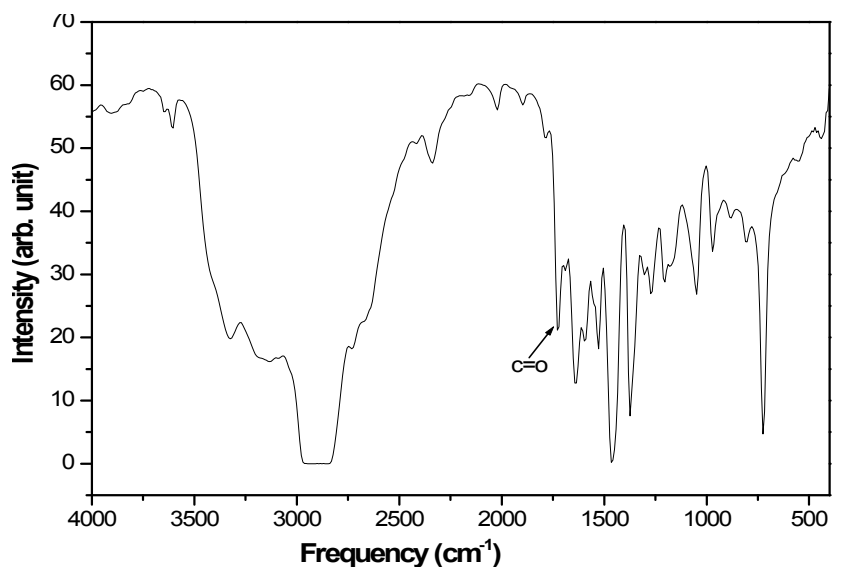

Figure 1(c). IR spectra of SATA-5.

between mEPDM and mHDPE molecules, which is depicted in Scheme 1. ${ }^{22,23}$

Plot of storage modulus as a function of temperature is shown in Figure 2, and the dynamic storage moduli of the samples at $30^{\circ} \mathrm{C}$ and $150^{\circ} \mathrm{C}$ are summarized in Table 2 . It is observed that storage modulus of SATA-0 continues to de

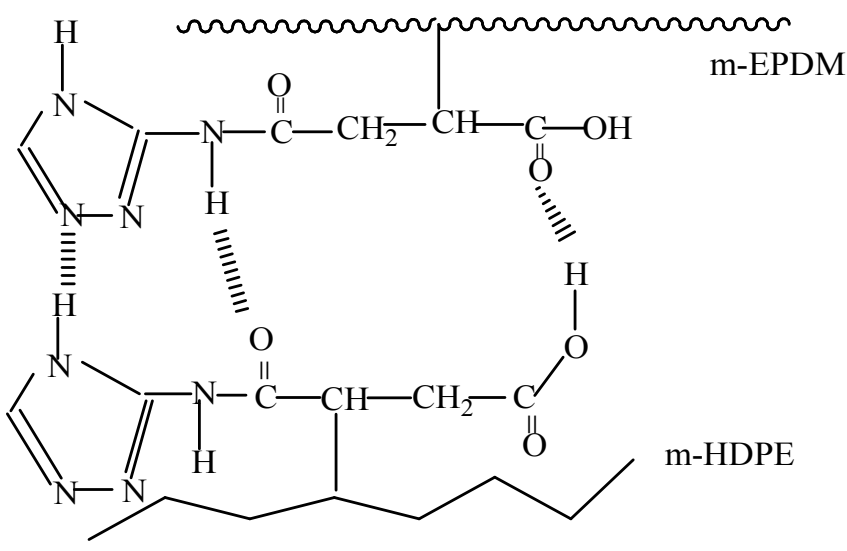

Scheme 1. Supramolecular hydrogen bonding in mEPDM/mHDPE/ATA blend. ${ }^{22,23}$

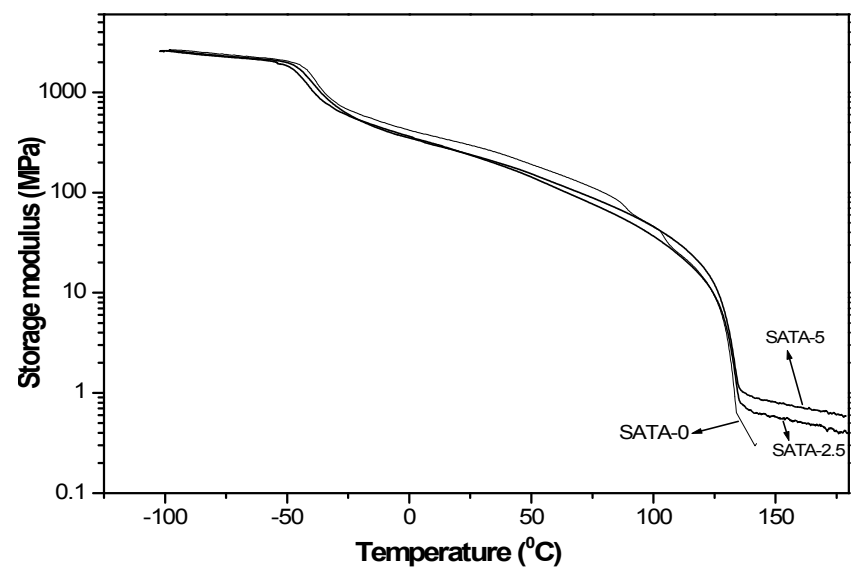

Figure 2. Temperature dependence of dynamic storage modulus of samples.

Table 1. Tensile Properties of Samples

\begin{tabular}{ccccc}
\hline Samples & $\begin{array}{c}\text { Tensile } \\
\text { strength } \\
(\mathrm{MPa})\end{array}$ & $\begin{array}{c}100 \% \\
\text { Modulus } \\
(\mathrm{MPa})\end{array}$ & $\begin{array}{c}\text { Elongation-a } \\
\text { t-break } \\
(\%)\end{array}$ & $\begin{array}{c}\text { Tension } \\
\text { set } \\
(\%)\end{array}$ \\
\hline SATA-0 & $8.8 \pm 0.4$ & $6.4 \pm 0.1$ & $950 \pm 50$ & 40 \\
SATA-2.5 & $11.6 \pm 0.3$ & $7.6 \pm 0.2$ & $1070 \pm 50$ & 28 \\
SATA-5 & $16.3 \pm 0.5$ & $8.9 \pm 0.2$ & $1290 \pm 70$ & 22 \\
\hline
\end{tabular}

Table 2. Dynamic Storage Modulus at $30^{\circ} \mathrm{C}$ and $150^{\circ} \mathrm{C}$

\begin{tabular}{ccc}
\hline Samples & $\mathrm{E}^{\prime} \begin{array}{r}\text { at } 30{ }^{\circ} \mathrm{C} \\
(\mathrm{MPa})\end{array}$ & $\mathrm{E}^{\prime} \begin{array}{c}\text { at } 150{ }^{\circ} \mathrm{C} \\
(\mathrm{MPa})\end{array}$ \\
\hline ATA-0 & $390 \pm 25$ & 0 \\
ATA-2.5 & $330 \pm 20$ & $0.6 \pm 0.02$ \\
ATA-5.0 & $330 \pm 20$ & $0.8 \pm 0.02$ \\
\hline
\end{tabular}

crease with temperature and the material flows like a viscous liquid when the temperature is greater than $T_{\mathrm{m}}$ of $\mathrm{mHDPE}$, whereas SATA-2.5 and SATA-5 show a persistent rubbery plateau above $T_{\mathrm{m}}$. The presence of a persistent rubbery plateau 


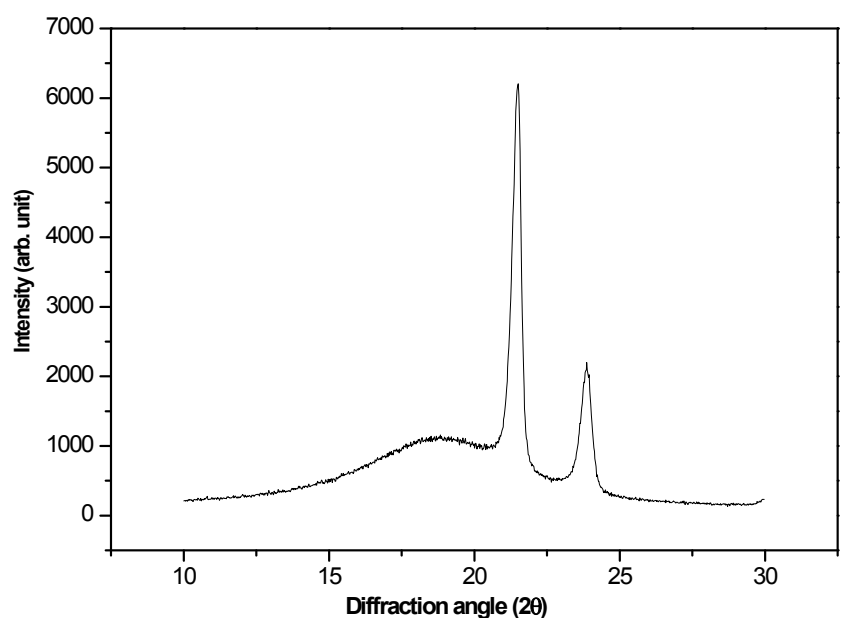

Figure 3(a). XRD of SATA-0.

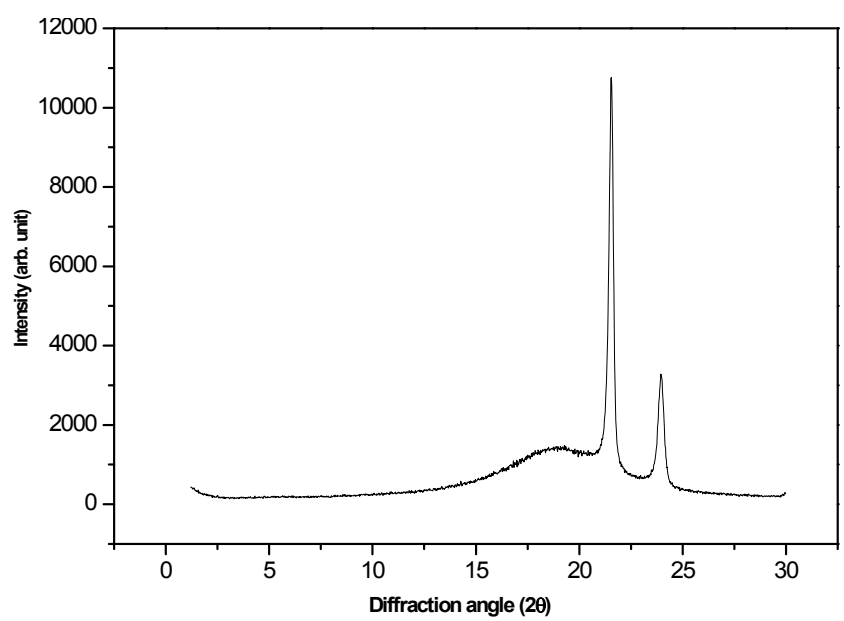

Figure 3(b). XRD of SATA-2.5.

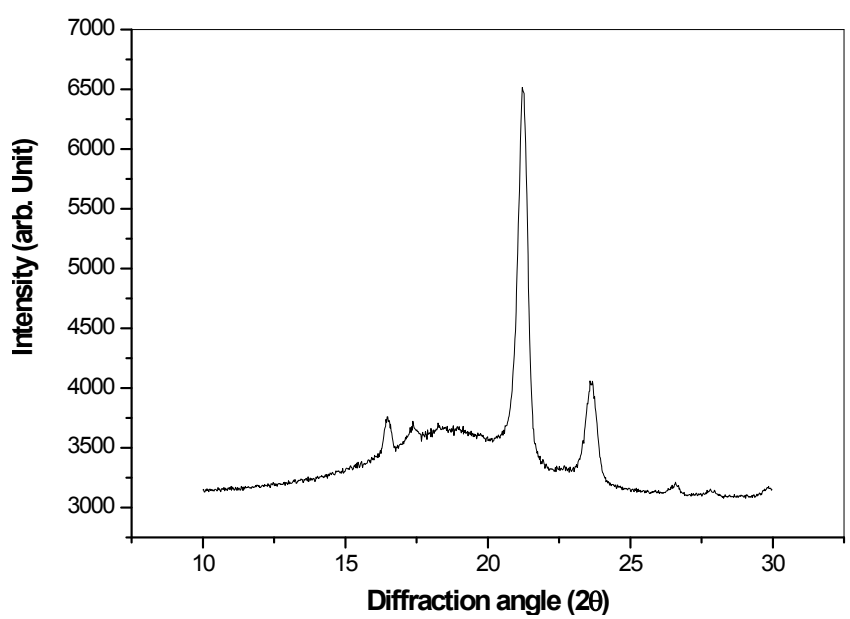

Figure 3(c). XRD of SATA-5.

in the blend with ATA indicates that the blend forms a crosslinked structure. At the rubbery plateau region, the blend with ATA shows higher storage modulus as compared to the blend without the ATA and it increases with increasing ATA content in the blend. This indicates that ATA can induce a crosslinked structure in the mHDPE/mEPDM blend and the degree of crosslinking increases with increasing ATA content in the blend. Network formation in the blend with ATA is ascribed to supramolecular hydrogen-bonding interactions between the ATA modified polymer chains, as was confirmed by FT-IR analysis. At room temperature, however, the storage moduli at the room temperature of the SATA-2.5 and SATA-5 is a little smaller than that of SATA-0, which can be explained in terms of decreased crystallinity of mHDPE arising from network formation in SATA-2.5 and SATA-5.

X-ray diffraction patterns of SATA-0, SATA-2.5 and SATA-5 are shown in Figure 3(a), (b) and (c), respectively. Distinct crystalline peaks appeared at $2 \theta$ values of $21.54^{\circ}$ and $23.92^{\circ}$ in Figure 3(a) are due to reflection of 110 and 200 planes of mHDPE. ${ }^{17}$ The degree of crystallinity of SATA-0, which is calculated using equation (2), is $21.4 \%$ whereas it is decreased to $20.9 \%$ and $20.3 \%$ in SATA-2.5 and SATA-5, respectively. This indicates that network structure in the blend with ATA disturbs the packing of the polymer molecules to some extent.

Phase morphology results of SATA- 0 and SATA- 5 examined by FE-SEM are presented in Figure 4(a) and (b), respectively. It is observed that the mEPDM phase is dispersed in continuous mHDPE matrix in both cases, but the particle sizes of the dispersed phase in SATA-5 are smaller than those in SATA-0. The number average domain size of the dispersed phase, measured by image analyzer (considering large number of particles), is $0.19 \mu \mathrm{m}$ and $0.12 \mu \mathrm{m}$ for SATA- 0 and SATA-5, respectively. The finer morphology in SATA-5 as compared to that in SATA-0 suggests that ATA induced compatibilization effects in the immiscible $\mathrm{mEPDM} / \mathrm{mHDPE}$ blend. The supramolecular hydrogen bonding interactions between MHDPE and MEPDM modified by ATA may reduce the interfacial tension of the blend, which results in the compatibilization of the blend system.

Tensile properties of the blends such as tensile strength, $100 \%$ modulus, elongation at break and tension set are shown in Table 1. It is observed that the tensile strength, 100\% modulus, elongation at break of the blend greatly improved with the addition of ATA. Only $5 \mathrm{phr}$ addition of ATA, tensile strength and $100 \%$ modulus of the blend increased by about $85 \%$ and $39 \%$, respectively. The enhancement in the strength and modulus is thought to be associated with finer morphology and the presence of pseudo-crosslinks in the blend. It is interesting to note that there is a concurrent increase in the modulus and elongation at break in the blend with ATA. It is suggested that this unique tensile behavior is due to strong interfacial adhesion between the component polymers arising from extensive hydrogen boning interactions between the polymer chains. It is to be noted that tension set value of the blend decrease with the addition of ATA. The tension set value of 


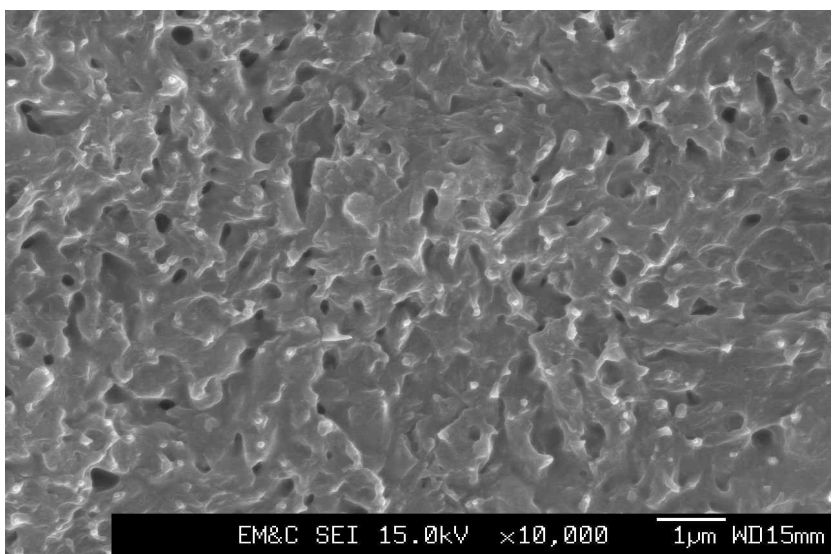

Figure 4(a). FE-SEM micrographs of fracture surface of SATA-0.

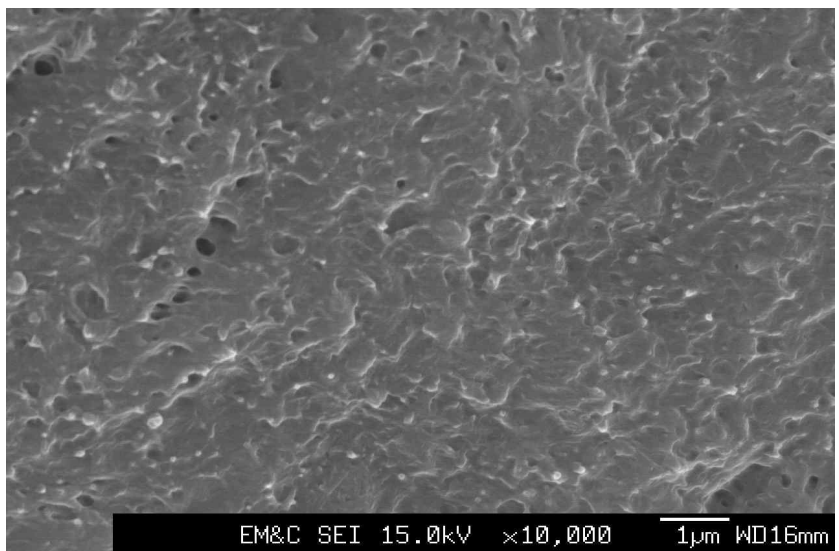

Figure 4(b). FE-SEM micrographs of fracture surface of SATA-5.

SATA- 0 is about $40 \%$, and it decreased to $28 \%$ and $22 \%$ for SATA-2.5 and SATA-5.0, respectively, indicating that the blends with ATA have high elastic recoverability like a vulcanized rubber. This can be explained in terms of finer dispersion of ATA crosslinked mEPDM rubber in semicrystalline HDPE matrix similar to dynamically vulcanized rubber/plastic blends. Melt rheology studies were carried out to assess the microstructure of the blend in melt state. Frequency dependences of both storage modulus $\left(\mathrm{G}^{\prime}\right)$ and complex viscosity $\left(\eta^{*}\right)$ of samples in molten state are shown in Figure 5(a) and (b), respectively. It can be seen that addition of ATA affects the rheological properties of the mEPDM/ mHDPE blend. Figure 5(a) shows that storage modulus increases with increaseing frequency in all the blend samples. When the polymer melt is deformed at higher frequency, polymer chains do not have less time to relax, so the modulus goes up. The results show that the blend with ATA has higher storage modulus as compared to that without ATA, and the modulus increases with increasing ATA content, especially at low frequency region, and the increase in the modulus is accompanied with a decrease in the terminal region slope. The higher modulus and

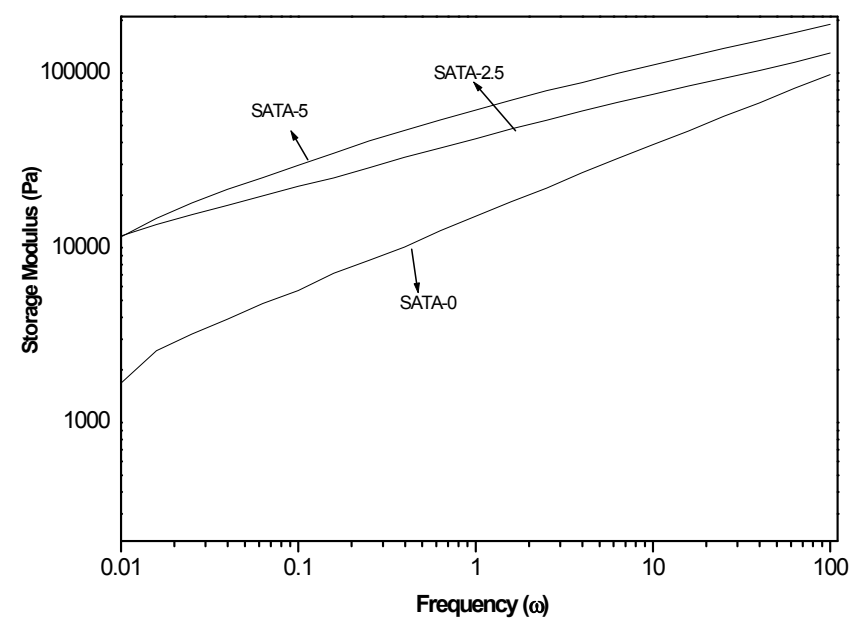

Figure 5(a). Frequency dependence of storage modulus of samples at melt state.

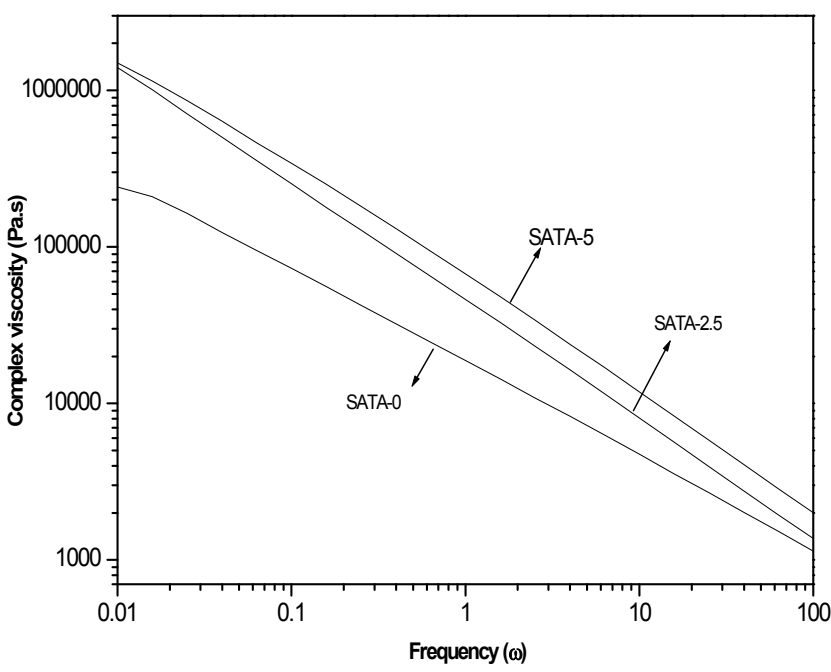

Figure 5(b). Frequency dependence of melt viscosity of samples.

smaller terminal slope of the blend with ATA over the blend without ATA indicate the formation of a three dimensional network structure in the blend with ATA. Figure 5(b) shows a plot of dynamic complex viscosity $\left(\eta^{*}\right)$ versus frequency, which reveals that the ATA induces an increase in the viscosity and higher shear thinning behavior. This is due to the crosslinked nature of the ATA modified blends. Such melt rheological behaviors have been commonly observed in a slightly crosslinked multiblock copolymer type elasomer ${ }^{25}$ as well as dynamically vulcanized elastomer/plastic blends. ${ }^{9,10}$

\section{Conclusions}

A small amount of 3-amino-1, 2, 4-triazole(ATA) was incorporated into a immiscible mEPDM/mHDPE (50 wt $\% / 50 \mathrm{wt} \%$ ) blend by a melt mixing process. Addition of ATA led to finer phase morphology, formation of physical crosslinks and im- 
proved mechanical properties along with high elastic recoverability of the blend. Melt state linear dynamic viscoelastic measurements revealed that ATA induced pseudo solid-like behavior as well as enhanced shear thinning in the blend.

\section{Acknowledgements}

This work was supported by the National Research Foundation of Korea (NRF) grant funded by the Korea government (MSIP) (NO.2005-0049406) and a grant (No. 405-111- 004) from EcoInnovation project funded by Ministry of Environment, Korea.

\section{References}

1. S. K. De and A. K. Bhowmick Ed, "Thermoplastic Elastomers from Rubber-Plastic Blends" Ellis Horwood, New York, 1990.

2. B. C. Kim, S. S. Hwang, K. Y. Lim, and K. J, Yoon, "Toughening of PP/EPDM blend by compatibilization", J. Appl. Polym. Sci., 78, 1267 (2000).

3. A. L. N. Da Silva and F. M. B. Coutinho, "Some properties of polymer blend based on EPDM/PP", Polym. Test., 15, 45 (1996).

4. H. Ismail and Suryadiansyah, "Thermoplastic elastomers based on polypropylene/natural rubber and polypropylene/recycle rubber blends", Polym. Test., 21, 389 (1996).

5. A. L. N. Da Silva, M. C. G. Rocha, F. M. B. Coutinho, R. E.S. Bretas, and M. Farah, "Evaluation of rheological and mechanical behavior of blends based on polypropylene and metallocene elastomers", Polym. Test., 21, 647 (2002).

6. Z. S. Fu, Z. Q. Fan, Y.Q. Zhang, and L. X. Feng, "Structure and morphology of polypropylene/poly(ethylene-co-propylene) in-situ blends synthesized by spherical Ziegler-Natta catalyst", Eur. Polym. J., 39, 795 (2003).

7. W. Feng and A. I. Isayev, "In situ compatibilization of PP/EPDM blends during ultrasound aided extrusion", Polymer, 45, 1207 (2004).

8. Y. Chen and H. Li, "Phase morphology evolution and compatibility improvement of PP/EPDM by ultrasound irradiation", Polymer, 46, 7707 (2005).

9. E. Prut, T. Medintseva, and V. Dreval, "Mechanical and rheological behavior of unvulcanized and dynamically vulcanized i-PP/EPDM blends", Macromol. Symp., 233, 78 (2006).

10. Y. Chen, C. Xu, L. Cao, Y. Wang, and X. Cao, "PP/EPDMbased dynamically vulcanized thermoplastic olefin with zinc dimethacrylate: preparation, rheology, morphology, crystallization and mechanical properties", Polym. Test., 31, 728 (2012).

11. S. George, R. Joseph, S. Thomas, and K.T. Varughese, "Blends of isotactic polypropylene and nitrile rubber: morphology, mechanical properties and compatibilization", Polymer, 36, 4405
(1995).

12. Z. Su, P. Jiang, Q. Li, P. Wei, G. Wang, and Y. Zhang, "Mechanical properties and morphological structures relationship of blends based on sulfated EPDM ionomer and polypropylene", J. Appl. Polym. Sci., 94, 1504 (2004).

13. P. Antony, S. Bandyopadhyay, and S. K. De, "Thermoplastic elastomers based on ionomeric polyblends of zinc salts of maleated polypropylene and maleated EPDM rubber", Polym. Eng. Sci., 39, 963 (1999).

14. P. Antony, S. Bandyopadhyay, and S. K. De, "Synergism in properties of ionomeric polyblends based on zinc salts of carboxylated nitrile rubber and poly(ethylene-co-acrylic acid)", Polymer, 41, 787 (2000).

15. P. Antony, S. Bandyopadhyay, and S. K. De, "Thermoplastic elastomers based on ionomeric polyblends of zinc salts of poly(propylene-co-acrylic acid) and carboxylated nitrile rubber", J. Mater. Sci., 34, 2553 (1999).

16. P. Antony and S. K. De, "Ionomeric polyblends of zinc salts of maleated EPDM rubber and poly(ethylene-co-acrylic acid). I. Effect of blend ratio", J. Appl. Polym. Sci., 71, 1247 (1999).

17. Antony, P. and De, S.K. Synergism in properties of ionomeric polyblends based on zinc salt of maleated high density polyethylene and carboxylated nitrile rubber. J. Appl. Polym. Sci., 70, 483 (1998).

18. T. T. M. Phan, A. J. Denicola Jr, and L.S. Schadler, "Effect of addition of polyoxy propylenediamine on the morphology and mechanical properties of maleated polypropylene/maleated rubber blends", J. Appl. Polym. Sci., 68, 1451 (1998).

19. K. Chino and M. Ashiura, "Thermoreversible cross-linking rubber using supramolecular hydrogen-bonding networks", Macromolecules, 34, 9201 (2001).

20. K. Chino, M. Ashiura, and J. Natori, "Thermoreversible crosslinking rubber using supramolecular hydrogen bonding networks", Rubb. Chem. Technol., 75, 713 (2002).

21. C. X. Sun, M.A.J. van der Mee, J.G.P. Goossens, and M. van Duin, "Thermoreversible cross-linking of maleated ethylene/propylene copolymers using hydrogen-bonding and ionic interactions", Macromolecules, 39, 3441 (2006).

22. Y.-W. Chang, J. K. Mishra, S. K. Kim, and D. K. Kim, "Effect of supramolecular hydrogen bonded network on the properties of maleated ethylene propylene diene rubber/maleated high density polyethylene blend based thermoplastic elastomer", Mater. Lett., 60, 3118 (2006).

23. J. K. Mishra, Y.-W. Chang, D. K. Kim, and P. L. Nayak, "Heat shrinkable behavior of supramolecular hydrogen bonded maleated ethylene propylene diene rubber/ maleated high density polyethylene blend", Polym. Plast. Technol. Eng., 46: 585 (2007).

24. L. E Alexander, "X-ray Diffraction in Polymer Science", Wiley Interscience, New York, 1969. 
25. N. B. Clothup, L. H. Daly, and S. E. Wibserley In Introduction to Infrared and Raman Spectroscopy, pp. 313-314, Academic Press Inc., New York, 1990.
26. M.C. Choi, J. Y. Jung, and Y.-W. Chang, "Peroxide modification of nylon 12 elastomer", Elast. Compos., 48, 18 (2013). 